\title{
Chronological events in the surgery of the septum
}

\author{
Manish Munjal ${ }^{1 *}$, Pankaj Arora1, Shubham Munjal'², Tulika Saggar1
}

${ }^{1}$ Department of ENT, ${ }^{2}$ Department of Anatomy, Dayanand Medical College, Ludhiana, Punjab, India

Received: 02 May 2020

Revised: 03 July 2020

Accepted: 04 July 2020

*Correspondence:

Dr. Manish Munjal,

E-mail: manishmunjaldr@yahoo.com

Copyright: ( ) the author(s), publisher and licensee Medip Academy. This is an open-access article distributed under the terms of the Creative Commons Attribution Non-Commercial License, which permits unrestricted non-commercial use, distribution, and reproduction in any medium, provided the original work is properly cited.

\begin{abstract}
Nasal obstruction unilateral or bilateral, secondary to congenital birth passage or adult, nasal trauma requires surgical intervention of the deviated septum. Intervention ranges from a minimal septal repositioning to submucosal resection, simple septoplasty or the extensive extracorporeal septoplasty. The development of septal surgery with the developments in the field of rhinology has been reviewed.
\end{abstract}

Keywords: Septal deviation, Septoplasty, Submucosal resection

\section{INTRODUCTION}

Deviations of nasal septum with an incidence of $44.8 \%$ necessitate surgical correction in only $2.1 \%$ with obstructive symptoms. ${ }^{1}$ The modus operandi of intervention is threefold, i.e. to facilitate equal bilateral nasal breathing and thereby alveolar ventilation as well as improve facial aesthetics. Limited resection of a bony spur with a "contact point neuralgia" and facilitating access to the middle meatus are the recent indications in this era of endoscopy. ${ }^{2}$ The development of septal surgery has passed through many phases from minimal to extensive surgical procedures.

\section{REVIEW OF LITERATURE}

The history of corrective procedures on deviations of the nasal septum dates from 1757 when Quelmatz described the technique of repositioning the deflected septum, by daily digital pressure. ${ }^{3}$ A century, later, Adams advocated fracturing \& splinting of the nasal septum. Ingals was the first to suggest the accomplishment of submucous operation by removal of a part of the triangular cartilage. ${ }^{4,5}$ Kreig improved the technique by resection of the entire deflected cartilage. ${ }^{6}$ Asch et al suggested actually altering the spring of the cartilage with full thickness crucial incisions. ${ }^{7}$ Boenninghaus completed the procedure by removal of the osseous septum (perpendicular plate of ethmoid and the vomer) as well as the cartilage. ${ }^{8}$ The submucous resection as we understand and perform today, was first described by Freer and Killian., ${ }^{9,10}$ They both, independently, recommended visualization of septal cartilage and the bone, while preserving the overlying mucosa. The mucosa was allowed to fall into medial apposition after the framework that help it off had been carefully removed. The principle of saving a dorsal cartilaginous strut was established to avoid collapse of the supratip by Freer, while Killian also preserved a caudal strut. ${ }^{10}$ Surgical refinements were suggested by Ballenger, Yankauer and Thompson. ${ }^{11-13}$ Submucous resection thus became the standard procedure for the rhinologist. There were still many inadequancies in the technique. A satisfactory buttress had to be left superiorly and anteriorly to prevent saddling and retraction of the columella. The limitations of this operation have been demonstrated by the various steps for improvement suggested by different rhinologic surgeons. These ranged from the simple shifting of the septum, it's incomplete removal and implantation of anterior struts, to complete removal and/or replacement by cartilaginous implants. 
These modifications have been proposed by Metzenbaum, Peer, Salinger et al, Fomon, et al, Becker, Cottle et al, Leirle et al, along with Peer et al designed techniques to deal with the caudal septum \& Metzenbaum's 'swinging door' technique ushered in an era of special interest in this branch of septal surgery. ${ }^{14-21}$ The era of modern septoplasty began with Cottle et al in the ensuing years, he $\&$ others (Goldman, Smith, Cottle) described the disadvantages of submucous resection and extolled the virtues of septoplasty methods. ${ }^{19,22-24}$ Borg et al, Stoksted, Pearson, Edward and Maran, all attempted to analyse the incidence and timing of the complications associated with submuscous resection. ${ }^{25-29}$ Septoplasty has to a large extent replaced submucous resection as the routine technique without solving all the problems of this type of surgery. The objective in the septoplasty operation is the restoration of normal anatomic relationship of the deflected septum, without or minimal sacrifice of its structures. This is especially required in children less than 17-18 years of age. Verwoerd et al considered it advisable to avoid actually performing the operation during either of the two nasal growth spurts. ${ }^{30}$ Moreover, septoplasty provides better functional results and results in fewer \& smaller perforations than submucous resection by Fjermedal et al. ${ }^{31}$

Recently, the permanent change in the shape of cartilage by morselization has been advocated by Rubin. ${ }^{32}$ The deviated cartilage is crushed by a morselizer after the mucosal flaps have been elevated on both sides and it is claimed that the new flattened shape of cartilage is retained on a permanent basis. Other conservative techniques such as partial or full thickness gridding, cross- hatching, excision with suture reapproximation of cartilage parts etc. all reflect an attitude that emphasizes preservation of cartilaginous tissue. The Gubish et al technique of removing the whole septum and reconstructing a new, straight, septum plane that is reimplanted is called extracorporeal correction and is the recent interventional aspect in septal surgery. ${ }^{33}$

\section{DISCUSSION}

Endoscopic assisted septoplasty and extracorporeal septoplasty are the recent developments in the surgery of the septum. The entire septal architecture can be visualised, the septum extracted, drilled, smoothened, straightened and repositioned back in its bed. The surgery is under magnification and deformities corrected likewise. Mucosal swelling in the valve area and restenosis, late sequele of a saddle nose and septal hematoma are the limitations of this intervention. ${ }^{34}$ Though for markedly crooked noses aesthetic outcome is comparable and functional superior with respect to, the in situ septal correction in rhinoplasty. ${ }^{35}$ Limited intervention is undertaken in the pediatric age group with unilateral flap elevation, preserving incisive nerves at the floor and, the dorsal keystone chondro-ethmoid plate as well as the dorsal sphenoethmoid region. This infact maintains the length and the height of the nose. ${ }^{36}$ Three dimensional print (3-D) technology has now been utilized to design training models with materials having properties similar to human tissues. These simulation models are the future, in the field of rhinology to improve the surgical dexterity manifold. ${ }^{37}$ The efficacy of the surgery of the deformed septum, seems intuitive with limited global literature available, on its utility. Studies report $70.5 \%$ success in relieving nasal obstruction Associated turbinoplasty or out fracture further improves the airway. ${ }^{38} \mathrm{~A}$ "full medical treatment", prior to surgical intervention definitely effects the patient satisfaction levels.

\section{CONCLUSION}

Septal corrective surgery aims to achieve a bilateral patent nasal airway internally and improve facial aesthetics externally.

Funding: No funding sources

Conflict of interest: None declared

Ethical approval: Not required

\section{REFERENCES}

1. Ahn JC, Lee WH, We J, Rhee CS, Lee CH, Kim JW, et al. Nasal septal deviation with obstructive symptoms: association found with asthma but not withother general health problems. Am J Rhinol Allergy. 2016;30(2):17-20.

2. Stammberger II, Wolf G. Headaches and sinus disease:the endoscopic approach. Ann Otol Rhinol Laryngol Suppl. 1988;134:3-23.

3. Quelmatz E. Hallers disputant and nosbarum. Paris. 1957.

4. Adams W. The treatment of the broken nose by forcible straightening and mechanical apparatus. $\mathrm{Br}$ Med J. 1875;2:421.

5. Ingals EF. Deflection of nasal septum. Tr Am Laryng. 1882;4:61-9.

6. Kreig R. Resection der cartaligo quadrangularis septi narium zus heilung der scoliosis septi. Med Cor-BI, Nurttems, artzl; ver, Stuttg. 1889;56:206-9.

7. Asch M. The treatment of nasal stenosis due to deflective septum with and without thickening of the convex side. Laryngoscope. 1899;6:340.

8. Boeninghaus G. Bemerbanger Zum Dufstaz Lowens Zur Chirugie die Nasencheidenaud Monatsschrf. Ohern. 1900;34:287.

9. Freer OT. The correction of deflections of nasal septum with minimum of traumatization. J.Am Med Assoc. 1902;38:636-42.

10. Killian G. Die mucosa fensterresktion der Nasencheidenaud. Arch Lryng: U Rhin. 1904;16:362-87.

11. Ballenger WL. A New technique for the submucous resection of the cartilaginous septum. The swivel septum knife. The Laryngoscope, 1905.

12. Yankauer S. Septoplasty Rational surgery of the nasal septum. The J Laryngol Otol. 1975. 
13. Thompson SC. Ocular Symptoms Produced by Nasal Disease1 HHB Cunningham. J Laryngol Otol. 1911

14. Metzenbaum M. Replacement of the lower end of the dislocated septal cartilage versus submucous resetion of the dislocated end of septal cartilage. Arch Otolaryngol. 1929;9:282.

15. Peer L. An operation to repair lateral displacement of the lower border of the septal cartilage. Arch Otolaryngol. 1937;25:475.

16. Salinger S. and Cohen D.M. Surgery of difficult septum. Arch Otolaryngol. 1992;177:528-30.

17. Fomon S, Gilbert JG, Silver AG, Syracuse VR. Plastic repair of obstructing nasal septum. Arch Otolaryngol. 1948;47:7.

18. Becker H. Paraffinoma as a complication of nsal packing. Plast Reconstr Surg. 1983;72:735-6.

19. Cottle, Loring R. Correcting surgery of the external nasal pyramif and the nasal septum for restoration of Normal Physiol. ENT Monthly. 1947;26:147.

20. Lierle DM, Huffman WC. A review of septal surgery. Southern Med J. 1950.

21. Galloway P, Hinderer F, Subramaniam V, Basheer M. Evolution of correction of the deviated nasal septum-A historical overview. Archives of Medicine; 2018.

22. Goldman RB. New techniques in surgery of DNS. Arch Otolaryngol. 1956;64:183-9.

23. Smith M. Abusive rhinology. $\mathrm{Br} \mathrm{J}$ Clin Pract 1975;13:458.

24. Cottle M. Concepts of nasal physiology as related to corrective nasal surgery. Arch Otolaryngol. 1960;72:11-20

25. Borg R, Vand D, Seimens B. Submucous septal correction. Pract Otorhinolaryngol. 1957;19:316-20.

26. Stoksted P. Long term results following septum surgery. Rhinology. 1969;7:53-5.

27. Pearson B, Goodman W. SMR, septoplasty and surgical relief of nasal obstruction and the mechanics of breathing. Arch Otolaryngol. 1973;83:135-9.

28. Edward N. Septoplasty, rational surgery of nasal septum. J. Laryngol Otol. 1974:89:875-929.

29. Maran A. Septoplasty. JLO Laryngol Otol. 1974:88:393.

30. Verwoerd CDA, Urbans NAM, Nijdam DC. The effects of nasal surgery on the growth of the nose and maxilla. Rhinology. 1979;17:53-63.

31. Fjermedal O, Saunte C, Pedersen S. Septoplasty and/or submucous resection? 5 nasal septal operations. JLO. 1988;102:796-8.

32. Rubin FF. Controlled tip sculpting with the morselizer. Arch Otolaryngol. 1983;109:160-3.

33. Gubisch W. The extracorporeal septum plasty: a technique to correct difficult nasal deformities. Plastic Reconstruct Surg. 1995;95(4):672-82.

34. Tasca I, Compadretti GC, Losano T, Boccio C, Lijdens Y. Nasal Valve Stabilization in Extracorporeal Septoplasty. J Oto Rec Surg. 2016;2(1):112.

35. Lee SB, Jang YJ. Treatment Outcomes of Extracorporeal Septoplasty Compared With in Situ Septal Correction in Rhinoplasty. JAMA Facial Plast Surg. 2014;16(5):328-34.

36. Cingi C. Septoplasty in Children. Am J Rhinol Allergy. 2016;30:42-7.

37. AlReefi MA, Nguyen LHP, Mongeau LG, Haq BU, Boyanapalli S, Hafeez N, et al. Development and Validation of a Septoplasty Training Model Using 3-dimensional Printing Technology. Int Forum Allergy Rhinol. 2017;7(4):399-404.

38. Samad I, Stevens HE, Maloney A. The efficacy of septal surgery. Otolaryngol. 1992;21(2);88-91.

Cite this article as: Munjal M, Arora P, Munjal S, Saggar T. Chronological events in the surgery of the septum. Int J Otorhinolaryngol Head Neck Surg 2020;6:1584-6. 